\title{
Temperature Effects on the Friction and Wear Behaviors of SiCp/A356 Composite against Semimetallic Materials
}

\author{
Like Pan, Jianmin Han, Zhiyong Yang, Jialin Wang, Xiang Li, \\ Zhiqiang Li, and Weijing $L i$ \\ School of Mechanical, Electronic and Control Engineering, Beijing Jiaotong University, Beijing 100044, China \\ Correspondence should be addressed to Jianmin Han; jmhan@bjtu.edu.cn
}

Received 24 January 2017; Accepted 11 April 2017; Published 24 May 2017

Academic Editor: Patrice Berthod

Copyright (c) 2017 Like Pan et al. This is an open access article distributed under the Creative Commons Attribution License, which permits unrestricted use, distribution, and reproduction in any medium, provided the original work is properly cited.

\begin{abstract}
Due to the low density and high temperature resistance, the SiCp/A356 composites have great potential for weight reduction and braking performance using the brake disc used in trains and automobiles. But the friction coefficient and braking performance are not stable in the braking process because of temperature rising. In this paper, friction and wear behaviors of $\mathrm{SiCp} / \mathrm{A} 356$ composite against semimetallic materials were investigated in a ring-on-disc configuration in the temperature range of $30^{\circ} \mathrm{C}$ to $300^{\circ} \mathrm{C}$. Experiments were conducted at a constant sliding speed of $1.4 \mathrm{~m} / \mathrm{s}$ and an applied load of $200 \mathrm{~N}$. Worn surface, subsurface, and wear debris were also examined by using SEM and EDS techniques. The third body films (TBFs) lubricated wear transferred to the third body abrasive wear above $200^{\circ} \mathrm{C}$, which was a transition temperature. The friction coefficient decreased and weight of semimetallic materials increased with the increase of temperature and the temperature had almost no effect on the weight loss of composites. The dominant wear mechanism of the composites was microploughing and slight adhesion below $200^{\circ} \mathrm{C}$, while being controlled by cutting grooves, severe adhesion, and delamination above the $200^{\circ} \mathrm{C}$.
\end{abstract}

\section{Introduction}

Particle reinforced aluminum alloy composites (PRACs) exhibit high specific strength and stiffness, high thermal conductivity, and good thermal resistance and have been used in a variety of structural applications ranging from civil transportation to aerospace $[1,2]$. PRACs have great potential to be used in the automobile and trains for the weight reducing and energy saving $[3,4]$. High and stable friction coefficient and low wear rates are requested in the braking process.

Some researchers have studied the friction properties under different load and sliding speed for the PRACs which were used in automobile. Natarajan et al. investigated the friction behavior of $25 \mathrm{wt} . \% \mathrm{SiCp} / \mathrm{A} 356$ composites against semimetallic material under different load and sliding velocity, and PRACs were found more suitable to be used as a candidate material for brake rotor application than cast iron [5]. Uyyuru et al. used the Al-Si-SiCp composite to study the wear rate and friction coefficient varied with the applied normal load and the sliding speed against the brake pad material. The applied normal load was found to be the most important parameter affecting wear performance [6]. A comparative experiment on wear resistance of brake materials against two different Al-MMCs brake drums was conducted on a Chase Machine by Zhang and Wang [7]. It was found that the friction coefficient continuously decreased with the increase of load and speed and converged gradually at temperatures of $177^{\circ} \mathrm{C}$ and $316^{\circ} \mathrm{C}$, and the friction fading took place at higher temperature. The changes of friction coefficient and wear rate at different load and speed range of the 20 vol.\% SiCp/A359 composites and cast iron were studied by Daoud and Abou El-khair, against a commercial automotive brake material on a pin-on-disc type apparatus. The result shows that the friction coefficient of the composite was higher than cast iron at all test conditions [8].

The tests above were undertaken at ambient temperature without considering the effect of temperature on friction performance. However, heat generation must be considered during braking which causes the surface temperature to 
increase with braking time and load increasing and affects the friction behavior during the sliding process. The mechanical properties and performance of the PRACs and the brake pad material decreased with the temperature rise [9-13]. So it is important to study the temperature effects on the friction behavior. Some researchers have studied the dry friction behavior under different environment temperature using a pin-on-disc type apparatus and investigated the effects of temperature on the friction behavior of the PRACs against the steel counterface.

Research on the influence of environment temperature on the wear behavior of Al-based composites has been made since 1993. Martinez et al. [14], Wilson and Alpas [15], Martín et al. [16], and Singh and Alpas [17] found that the presence of reinforcing particle extended the temperature range compared with aluminum alloys which were used in wear limited applications, such as piston liners and cylinder heads for car engines or brake drums and rotors [18]. Muratoğlu and Aksoy studied abrasive wear of the $25 \mathrm{vol} . \% \mathrm{SiCp} / 2124 \mathrm{Al}$ composites on a pin-on-disc type machine against abrasive paper. Result showed that the wear rate of $25 \mathrm{vol} . \% \mathrm{SiCp} / 2124 \mathrm{Al}$ composites increased significantly with temperature till $50^{\circ} \mathrm{C}$. For the tests at temperatures above $50^{\circ} \mathrm{C}$, the temperature had almost no effect on the wear rate [19]. Yao-hui et al. reported that the wear rate of both $\mathrm{Al}-12 \% \mathrm{Si}$ alloy and its composite reinforced with 4 vol. $\% \mathrm{C}_{\mathrm{f}}$ and $12 \% \mathrm{Al}_{2} \mathrm{O}_{3} \mathrm{f}$ decreased with temperature in the mild wear regime [20]. They showed that transition temperature increased about $200^{\circ} \mathrm{C}$ with addition of the reinforcements. A comparative investigation on dry sliding wear behaviors of $20 \mathrm{vol} . \% \mathrm{Al}_{2} \mathrm{O}_{3}$ p/6061Al composite and unreinforced 6061Al against a SAE 52100 bearing steel counterface was conducted on the ring-on-flat configuration in the temperature range of $25^{\circ} \mathrm{C}$ to $500^{\circ} \mathrm{C}$ by Singh and Alpas. It was found that the $\mathrm{Al}_{2} \mathrm{O}_{3}$ reinforcing particles lead to an increase in the transition temperature from $180^{\circ} \mathrm{C}$ for the unreinforced alloy to around $250^{\circ} \mathrm{C}$ for its composite [21]. Rodríguez et al. [22] carried out tests at different pressures and temperatures on $15 \mathrm{vol} \% \mathrm{SiCp} / 8090 \mathrm{Al}$ composite sliding against carbon steel (SAE 1045) on a pin-on-disc configuration. It was concluded that wear rate increased about two orders of magnitude when temperature was above a critical one. Mousavi Abarghouie and Seyed Reihani investigated the friction and wear behaviors of 20 vol. $\% \mathrm{SiCp} / 2024 \mathrm{Al}$ composite and $2024 \mathrm{Al}$ at elevated temperature range $20-250^{\circ} \mathrm{C}$ using a pin-on-disc apparatus and found that transition from mildto-severe wear above a critical temperature [23]. Labib et al. reported the tribological behavior of the $5-15$ vol.\% $\mathrm{SiCp} / \mathrm{Mg}$ composite and pure $\mathrm{Mg}$ sliding against AISI/SAE 52100 steel disk on pin-on-disk wear tests at temperature of $25-200^{\circ} \mathrm{C}$ [24]. It was found that the transition from a mild wear to a severe wear extended to a higher load at higher temperatures. However, in these tests MMCs were tested against steel counterface under different environment temperature and without considering the friction heat produced during the dry sliding process.

With friction time increased, temperature rises during the dry sliding process and results in performance degradation and unstable friction properties, which is different with the result of environment temperature. The dry sliding process of
TABLE 1: Nominal chemical composition of A356/Wt.\%.

\begin{tabular}{lccccccc}
\hline Element & $\mathrm{Si}$ & $\mathrm{Mg}$ & $\mathrm{Ti}$ & $\mathrm{Fe}$ & $\mathrm{Cu}$ & $\mathrm{Mn}$ & $\mathrm{Ni}$ \\
\hline Wt.\% & 7.23 & 0.332 & 0.128 & 0.112 & 0.001 & 0.001 & 0.001 \\
\hline
\end{tabular}

TABle 2: Nominal chemical composition of SiC/Wt.\%.

\begin{tabular}{lccccc}
\hline Element & $\mathrm{SiC}$ & $\mathrm{C}$ & $\mathrm{Si}$ & $\mathrm{SiO}_{2}$ & $\mathrm{Fe}_{2} \mathrm{O}_{3}$ \\
\hline Wt.\% & 97.2 & 0.28 & 0.23 & 1.73 & 0.56 \\
\hline
\end{tabular}

the PRACs is a complex process involving not only mechanical but also thermal and chemical interactions between the surfaces in contact. The temperature, produced by the friction heat, is one of the important factors, which influence the performance and surface topography of two rubbing materials. Researchers studied the friction behavior for the PRACs against steel materials at high temperature, or the friction properties for the PRACs against brake pad materials under room temperature using pin-on-disc type apparatus. However, the friction properties are not yet understood well for the PRACs against semimetallic materials with friction heat, and the friction characteristics are also changing with the varied counterface materials against PRACs.

This paper was concerned with the friction and wear behaviors of $\mathrm{SiCp} / \mathrm{A} 356$ composites against semimetallic brake materials. The transition from the mild-to-severe wear during sliding was studied at various temperatures on a ring-on-disc configuration. The effect of friction heat on wear behavior of the composites was studied at a constant sliding speed of $1.4 \mathrm{~m} / \mathrm{s}$ and load of $200 \mathrm{~N}$. Moreover, the worn surfaces and subsurface regions of the composites at different test temperatures were analyzed to investigate the wear mechanisms.

\section{Experimental Procedure}

2.1. Materials. The materials used for the wear test samples were $\mathrm{SiCp} / \mathrm{A} 356$ composites containing 20 vol. $\% \mathrm{SiC}$ particle which is produced by Beijing Jiaotong University. The studied composites were subjected to solution and precipitation heat treatment (T6). The material was produced using stirring casting and the average size of the $\mathrm{SiC}$ particle was $20 \mu \mathrm{m}$. The nominal chemical compositions of the A356 and SiC are shown in Tables 1 and 2, respectively. The microstructure of $\mathrm{SiCp} / \mathrm{A} 356$ composites is presented in Figure 1.

A commercial semimetallic phenolic brake pad material was used as the counterbody material, which contained binder materials (phenolic resin and rubber), reinforced fiber materials (steel fibers and so on), filler materials $\left(\mathrm{BaSO}_{4}\right.$, $\mathrm{CaCO}_{3}$, and so on), and others as friction modifier materials.

2.2. Experimental Techniques. Dry sliding wear tests were performed in the air using a ring-on-disc apparatus, which is shown in Figure 2. The ring specimens were made of $\mathrm{SiCp} / \mathrm{A} 356$ composites and it was loaded against a semimetallic material disc, which was $34 \mathrm{~mm}$ in diameter and $6 \mathrm{~mm}$ in thickness. The size of ring was $32 \mathrm{~mm}$ in outer diameter 


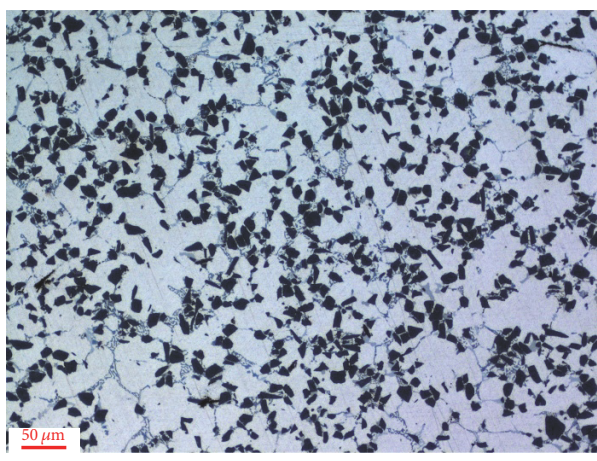

(a)

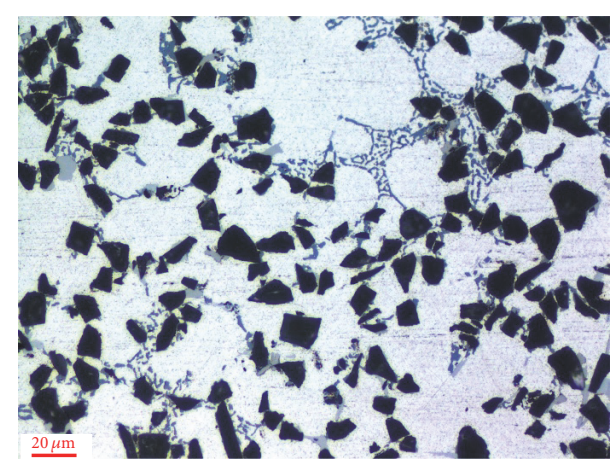

(b)

FIgURE 1: Microstructure of SiCp/A356 composites: (a) 200x and (b) 500x.

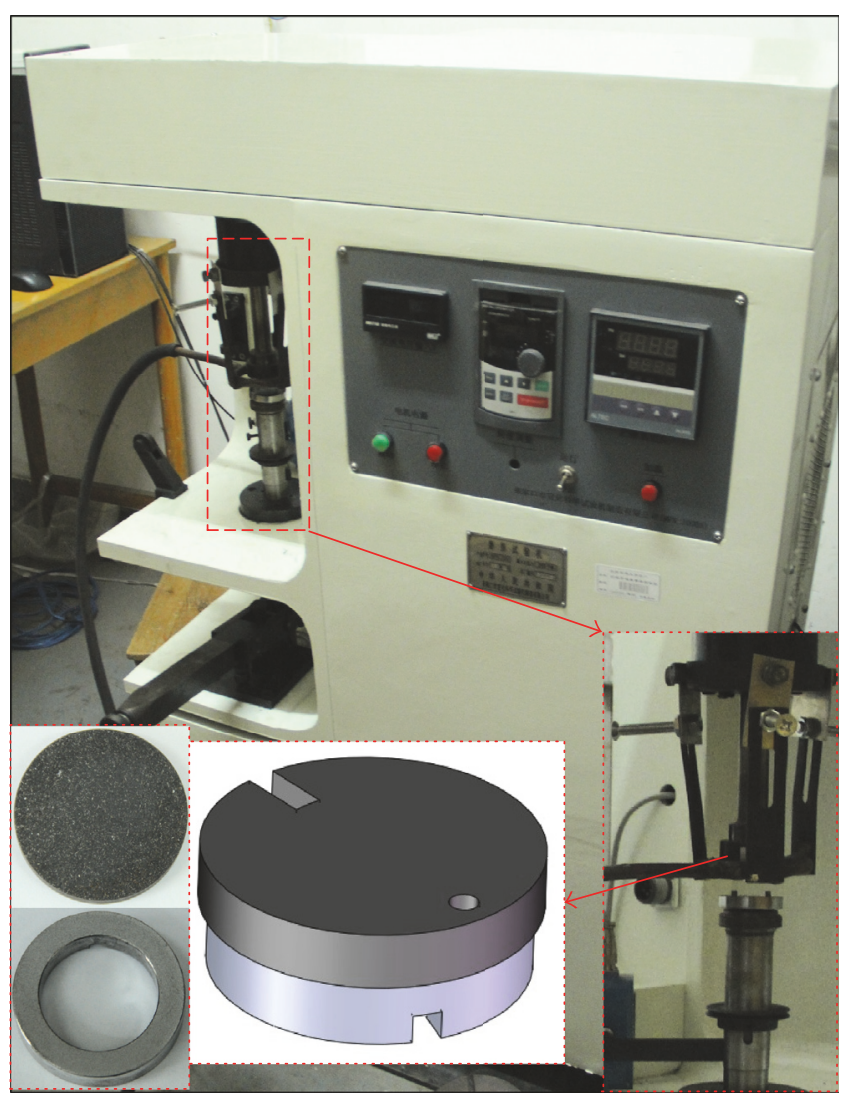

FIGURE 2: The ring-on-disc testing equipment.

and $7 \mathrm{~mm}$ in height. The size of the specimens is shown in Figure 3.

The counterface surfaces of specimens were polished on 1000-grit SiC paper before the wear test. The tests were carried out at a constant sliding speed of $1.4 \mathrm{~m} / \mathrm{s}$ and the applied load of $200 \mathrm{~N}$. The test stopped until the temperature of the ring specimen reached the required temperature.

Before and after each dry sliding wear test, the specimens of disc and ring were cleaned in alcohol, dried by air, and then weighed by using an electronic balance which was accurate to within $0.1 \mathrm{mg}$. The wear rates were calculated from the rate of weight loss to the friction work, which can be calculated by formula, $A=\left(W_{0}-W_{1}\right) / Q$, where $A$ is the wear rates (g/MJ), $W_{0}$ and $W_{1}(\mathrm{~g})$ are weight before and after wear test, respectively, and $Q(\mathrm{MJ})$ is the friction work recorded by the equipment. The initial weight of disc and ring is $16.1729 \mathrm{~g}$ and 8.8986 g, respectively.

The friction coefficient was measured as the ratio of the friction torque to the applied load and arm of load. The frictional torque was recorded by a torque transducer attached to the wear apparatus. And the friction coefficient was calculated and recorded during the dry sliding test.

The sliding wear tests were carried out in a temperature range from $30^{\circ} \mathrm{C}$ to $300^{\circ} \mathrm{C}$. The temperature range was divided into five temperature levels of $30^{\circ} \mathrm{C} \sim 100^{\circ} \mathrm{C}, 30^{\circ} \mathrm{C} \sim$ $200^{\circ} \mathrm{C}, 30^{\circ} \mathrm{C} \sim 300^{\circ} \mathrm{C}, 100^{\circ} \mathrm{C} \sim 200^{\circ} \mathrm{C}$, and $200^{\circ} \mathrm{C} \sim 300^{\circ} \mathrm{C}$. The temperature of contact surfaces was measured by using a thermocouple fixed on the $\mathrm{SiCp} / \mathrm{A} 356$ composites specimen close to the contact surface. The samples tested at $100^{\circ} \mathrm{C} \sim$ $200^{\circ} \mathrm{C}$ and $200^{\circ} \mathrm{C} \sim 300^{\circ} \mathrm{C}$ were heated to the lower level by a resistance heating furnace. And the temperature would reach the higher level of the temperature range during friction process because of the generation of friction heat. The worn surface and wear debris were observed and analyzed by scanning electron microscope (SEM) and energy dispersive spectroscope (EDS). For subsurface observations, tested specimens of SiCp/A356 composites were cut along the sliding direction and metallographically polished.

\section{Results and Discussion}

3.1. Friction and Wear Behavior. The friction coefficient and temperature changing with sliding time during the wear test are shown in Figure 4 . It can be seen that the temperature rises with the sliding time during the dry sliding process because of the generation friction heat. The friction coefficient decreases slowly with an increase in sliding time. Due to the external preheating with the resistance heating furnace, the temperature rises fast during the temperature range of $100^{\circ} \mathrm{C} \sim 200^{\circ} \mathrm{C}$ and $200^{\circ} \mathrm{C} \sim 300^{\circ} \mathrm{C}$. The friction coefficient has great fluctuation for test under the temperature of $200^{\circ} \mathrm{C} \sim$ $300^{\circ} \mathrm{C}$. 


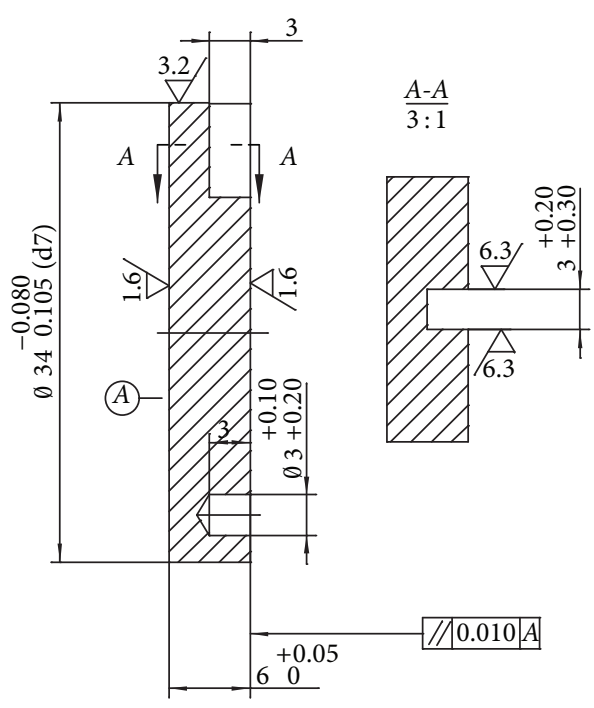

(a)

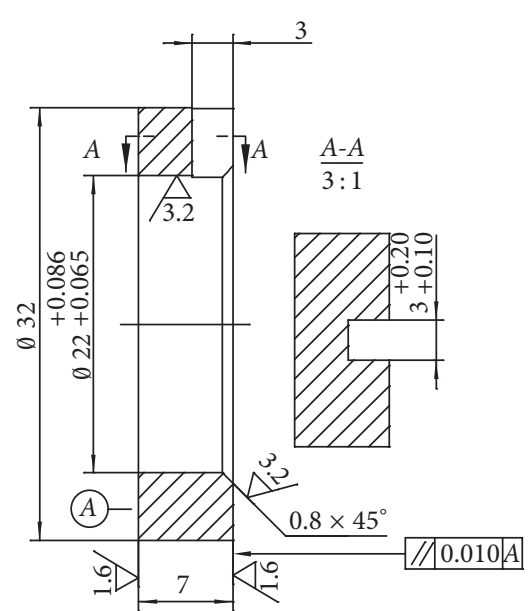

(b)

Figure 3: Dimensions of wear tests specimen: (a) disc and (b) ring.

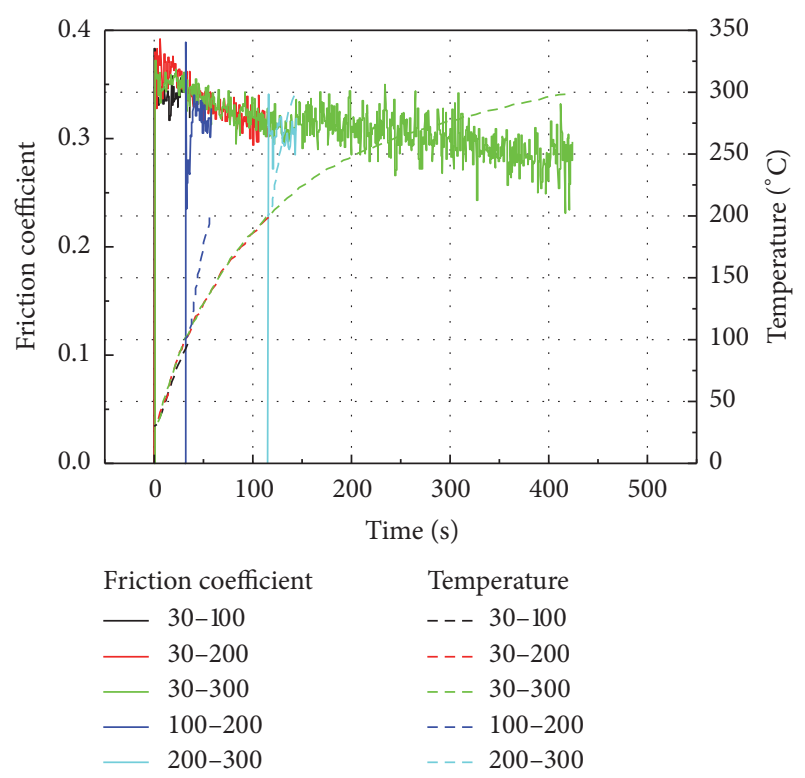

FIGURE 4: The friction coefficient and temperature change with the sliding time.

Figure 5 shows the average friction coefficient and wear rates for five temperature levels. The average friction coefficient decreased slowly with the increase of temperature during the tests under temperature level of $30^{\circ} \mathrm{C} \sim 100^{\circ} \mathrm{C}$, $30^{\circ} \mathrm{C} \sim 200^{\circ} \mathrm{C}$, and $30^{\circ} \mathrm{C} \sim 300^{\circ} \mathrm{C}$. And the friction coefficient was higher in the test of $100^{\circ} \mathrm{C} \sim 200^{\circ} \mathrm{C}$, while the lowest friction coefficient appeared in the test of $200^{\circ} \mathrm{C} \sim 300^{\circ} \mathrm{C}$. However, the average friction coefficient was about 0.3 and showed little difference on the average value of the friction coefficient for five temperature levels. The largest difference was found to be $16.7 \%$. It indicates that the $\mathrm{SiCp} / \mathrm{A} 356$

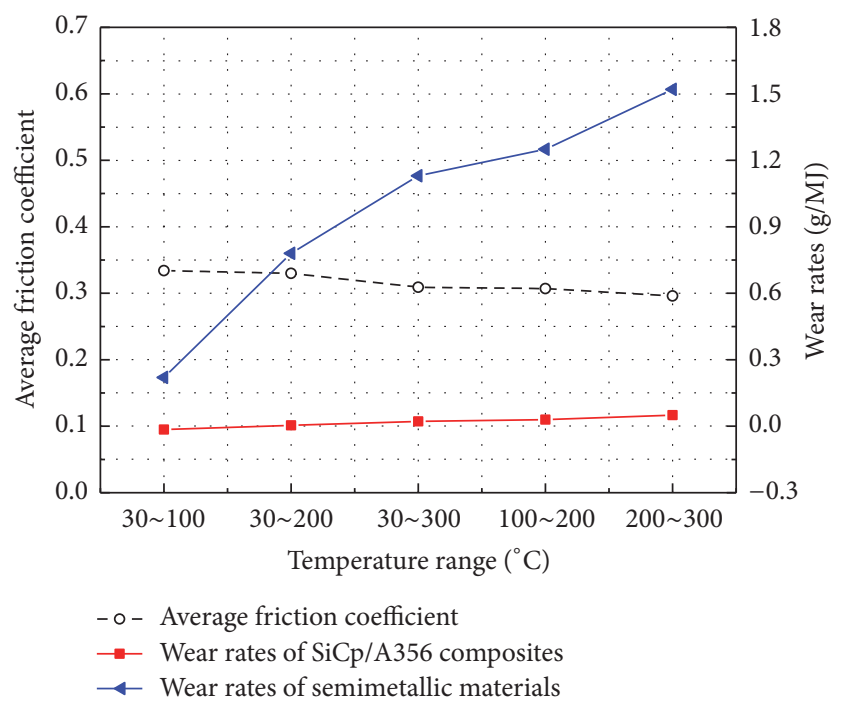

FIGURE 5: The average friction coefficient and wear rates for different temperature ranges.

composites have stable friction coefficient in the friction tests when coupling against a semimetallic material.

The wear rates of semimetallic materials increased obviously with the increase of temperature in the test of $30^{\circ} \mathrm{C} \sim$ $100^{\circ} \mathrm{C}, 30^{\circ} \mathrm{C} \sim 200^{\circ} \mathrm{C}$, and $30^{\circ} \mathrm{C} \sim 300^{\circ} \mathrm{C}$. The highest value of wear rates was observed in the test of $200^{\circ} \mathrm{C} \sim 300^{\circ} \mathrm{C}$, which was $1.52 \mathrm{~g} / \mathrm{MJ}$. Wear rate in the test of $100^{\circ} \mathrm{C} \sim 200^{\circ} \mathrm{C}$ was also higher. The wear rate in the test of $200^{\circ} \mathrm{C} \sim 300^{\circ} \mathrm{C}$ was nearly seven times of $30^{\circ} \mathrm{C} \sim 100^{\circ} \mathrm{C}$, which was $0.22 \mathrm{~g} / \mathrm{MJ}$. The wear rates of SiCp/A356 composites increased with rising of temperature, but the fluctuation amplitude was very small. The highest value of the wear rate was $0.05 \mathrm{~g} / \mathrm{MJ}$, which occurred in the test of $200^{\circ} \mathrm{C} 300^{\circ} \mathrm{C}$. It reveals that 


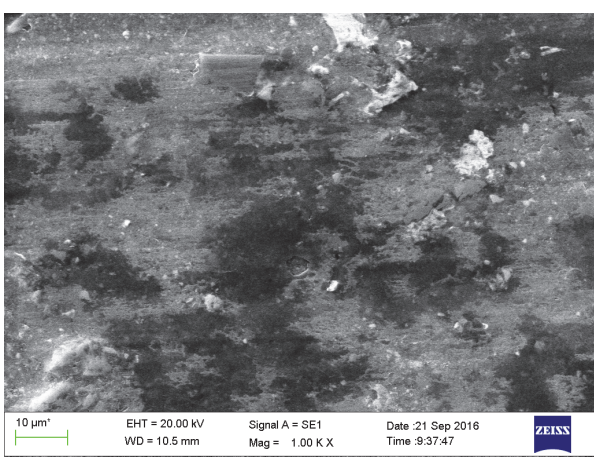

(a)

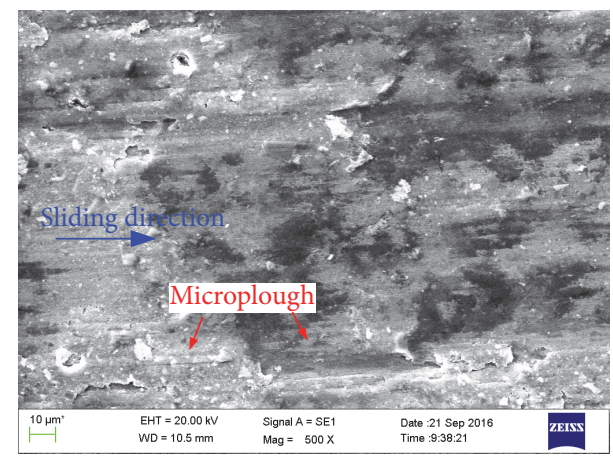

(b)

FIGURE 6: The worn surface topography of composites specimen for the test of $30^{\circ} \mathrm{C} \sim 100^{\circ} \mathrm{C}$ : (a) $1000 \mathrm{x}$ and (b) $500 \mathrm{x}$.

the temperature has almost no effect on the weight loss of SiCp/A356 composite.

The result shows that the temperature has important effect on the friction properties. The friction coefficient decreased slowly and became not smooth with the temperature rising. The wear rates have great increase with the temperature rising for the cumulative friction heat. There are lower friction coefficient and higher wear rates for the higher temperature.

3.2. Wear Mechanism. A layer of surface film was formed on the surface of the PRACs composite material in the dry sliding process due to the accumulation and compaction of transfer debris. The formation of this film could stable the friction coefficient and reduce the wear rate [25, 26]. Figures 6 and 7 show the worn surface and subsurface topography after dry sliding test under the temperature level of $30^{\circ} \mathrm{C} \sim 100^{\circ} \mathrm{C}$. It can be seen that there is a continuous layer of third body films (TBFs) which are $3 \sim 5 \mu \mathrm{m}$ in thickness and continuously distributed. The TBFs are a composite of elements of $\mathrm{Al}$, $\mathrm{Si}, \mathrm{Ca}, \mathrm{Fe}, \mathrm{C}, \mathrm{O}, \mathrm{Mg}$, and $\mathrm{S}$. The elements of $\mathrm{Al}, \mathrm{Si}$, and $\mathrm{Mg}$ were mainly from the $\mathrm{SiCp} / \mathrm{A} 356$ composites, while the elements of $\mathrm{Ca}, \mathrm{Fe}$, and $\mathrm{S}$ represented the transferring of the material from the semimetallic specimen. The elements $\mathrm{C}$ and O were transferred products of both SiCp/A356 composites and semimetallic materials.

The TBFs, also called tribolayers or mechanical mixed layers, are third body materials which are different from the two-body grinding materials. The TBFs could isolate the friction heat and bear the load [27]. The TBFs are composite of the materials of both $\mathrm{SiCp} / \mathrm{A} 356$ composites and semimetallic materials, and the content of each material is determined by the hardness of each grinding material [28]. There was mild abrasive wear on the surface of TBFs for the test under the temperature level of $30^{\circ} \mathrm{C} \sim 100^{\circ} \mathrm{C}$. Figure 6 exhibits the traces of slight abrasive wear and microplough on the TBFs. Due to the existence of the TBFs on the surface of $\mathrm{SiCp} / \mathrm{A} 356$ composites, the direct contact of twobody materials of SiCp/A356 composites and semimetallic materials can be avoided during dry sliding. Therefore, the TBFs can protect the surface of SiCp/A356 composites from wear and reduce the wear rates.
With the increase of temperature during the dry sliding process due to the friction heat, some damage appeared on the surface of TBFs. The integrity of the surface films was gradually destroyed and the TBFs became loose. With plenty of voids, adhesive pits appeared on the TBFs in the temperature range of $30^{\circ} \mathrm{C} \sim 200^{\circ} \mathrm{C}$. Microplough and delamination can also be seen in Figure 8.

The TBFs are made up of the SiCp/A356 composites and the semimetallic materials, which are mixed with the material such as the debris and accompanied by a variety of chemical reactions in the process of friction [6]. Figure 9 presents the element distribution of TBFs in position P1 of Figure 8 (b) for the test under temperature range of $30^{\circ} \mathrm{C} \sim$ $200^{\circ} \mathrm{C}$. The surface of $\mathrm{SiCp} / \mathrm{A} 356$ composites was exposed due to the delamination of TBFs and was damaged without the protection of TBFs. The TBFs contain the elements of $\mathrm{Al}, \mathrm{Si}$, and $\mathrm{Mg}$, which come from SiCp/A356 composites. And the elements of $\mathrm{Fe}, \mathrm{Ca}, \mathrm{Ba}$, and $\mathrm{S}$ in the TBFs were transferred from semimetallic materials. The elements of $\mathrm{C}$ and $\mathrm{O}$ cover all surfaces of specimens all the time.

The thermal expansion coefficient and performance degradation were different for the TBFs with the increase of temperature. As is shown in Figure 8(b), it leads to the formation of voids, the emergence of a variety of mild delamination and adhesion, and the wear with microplough at the same time. There was microcrack found on surface of TBFs, which could cause further damage of the TBFs when the cracks were connected with voids and adhesive pits. The friction coefficient reduced gradually with the rising temperature for the test of $30^{\circ} \mathrm{C} \sim 200^{\circ} \mathrm{C}$. The growth of wear rates of semimetallic materials was more than three times for the test of $30^{\circ} \mathrm{C} \sim 200^{\circ} \mathrm{C}$ than of $30^{\circ} \mathrm{C} \sim 100^{\circ} \mathrm{C}$. The result of wear rates was due to the damage of the TBFs.

As is shown in Figures 10(a) and 10(b), severe wear appeared in the temperature range of $30^{\circ} \mathrm{C} \sim 300^{\circ} \mathrm{C}$ and many grooves and adhesive pit have appeared in the worn surface. It can be seen from Figure 10 that a large number of surfaces of SiCp/A356 composites were exposed without coverage of TBFs. The existence of Al elements in Figure 10(d) proved the exposure of surface of $\mathrm{SiCp} / \mathrm{A} 356$ composites. The existence of Fe elements which can be observed in Figure 10(c) is the evidence of the existence of transferred debris. 


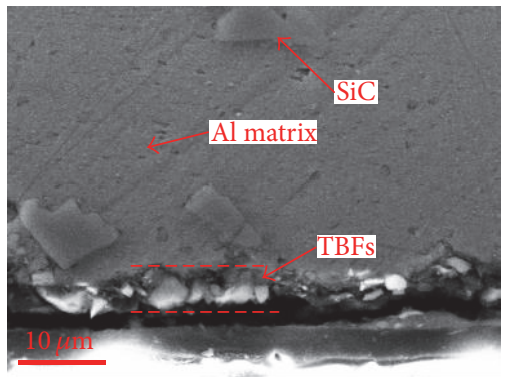

(a)

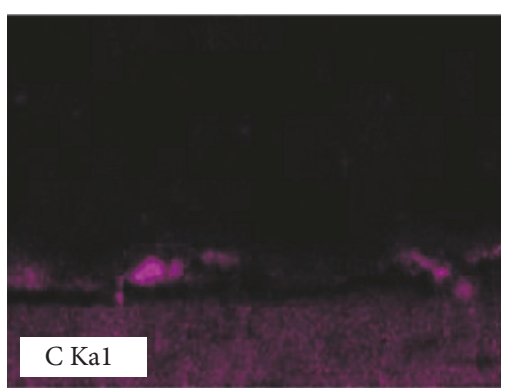

(d)

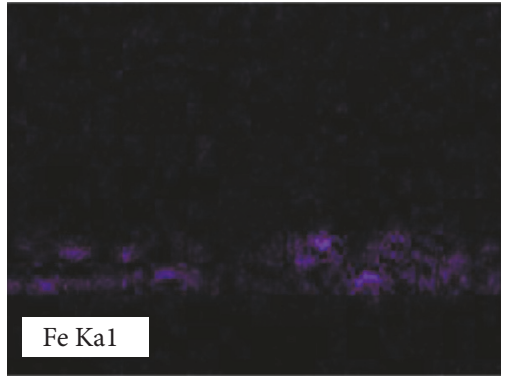

(g)

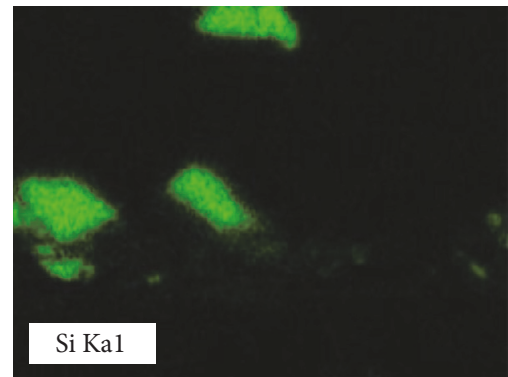

(b)

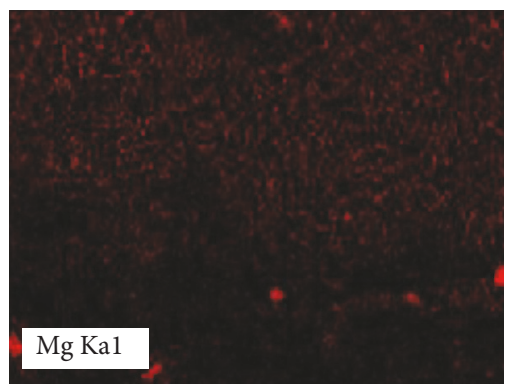

(e)

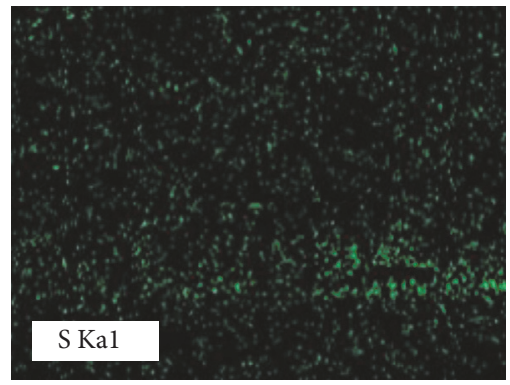

(h)

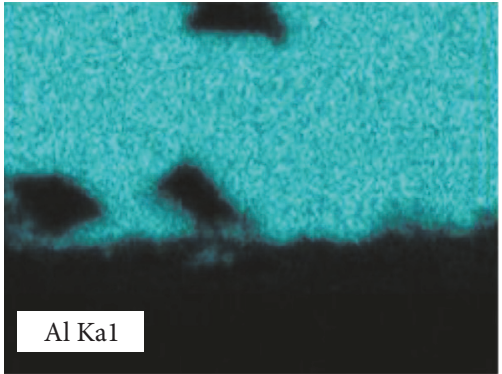

(c)

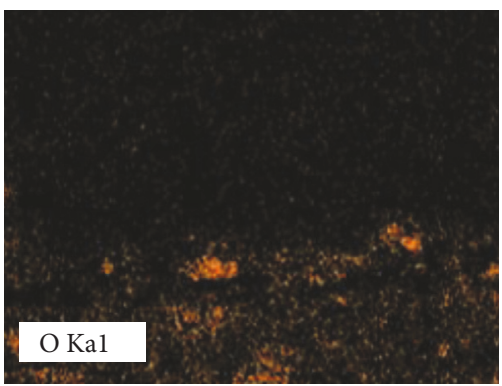

(f)

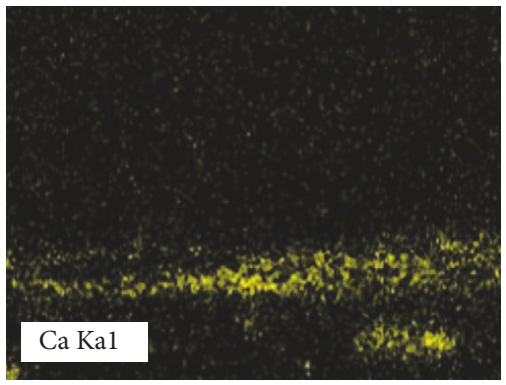

(i)

Figure 7: The subsurface topography and element distribution of composites specimen for the test of $30^{\circ} \mathrm{C} 100^{\circ} \mathrm{C}$ : (a) subsurface topography, (b) Si, (c) Al, (d) C, (e) Mg, (f) O, (g) Fe, (h) S, and (i) Ca.

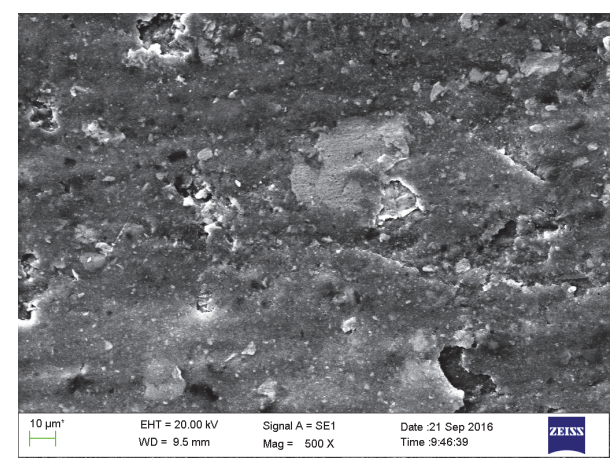

(a)

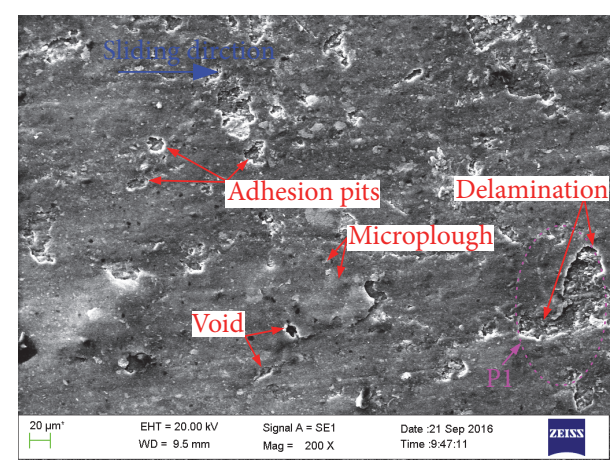

(b)

FIGURE 8: The worn surface topography of composites specimen for the test of $30^{\circ} \mathrm{C} 200^{\circ} \mathrm{C}$ : (a) $500 \mathrm{x}$ and (b) $200 \mathrm{x}$.

When temperature reached $300^{\circ} \mathrm{C}$, the continuous TBFs on the surface of SiCp/A356 composites were destroyed gradually. Then it was transformed into a status of discrete distribution, which reduced the load carrying capacity. Coupled with the effect of oxidation, delamination, and severe adhesion, the massive mechanically mixed particles (MMPs) which approximate spherical shape were produced under compressive force, which is as shown in Figure 11(a). The 


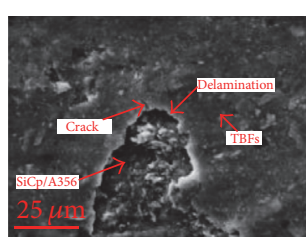

(a)

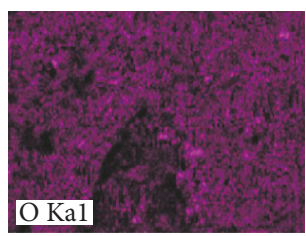

(f)

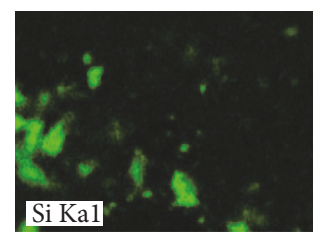

(b)

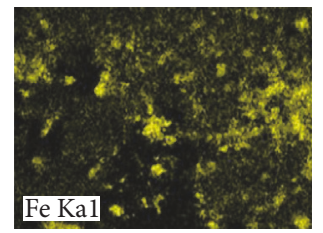

(g)

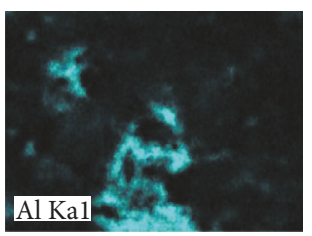

(c)

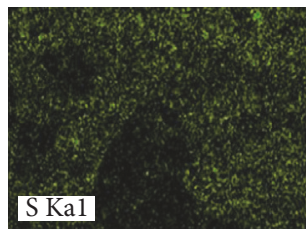

(h)

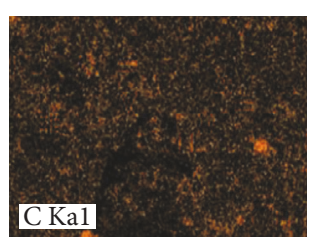

(d)

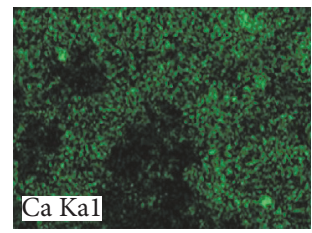

(i)

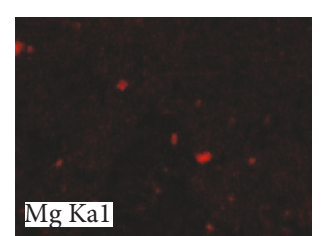

(e)

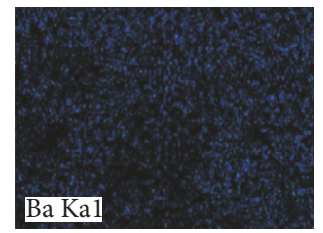

(j)

Figure 9: The surface topography and element distribution of position P1: (a) surface topography, (b) Si, (c) Al, (d) C, (e) Mg, (f) O, (g) Fe, (h) S, (i) $\mathrm{Ca}$, and (j) Ba.

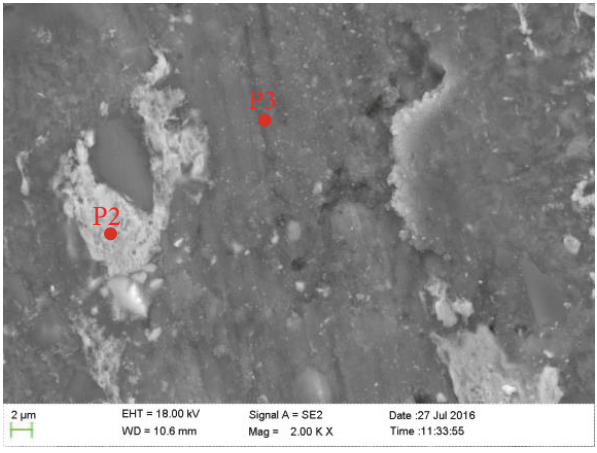

(a)

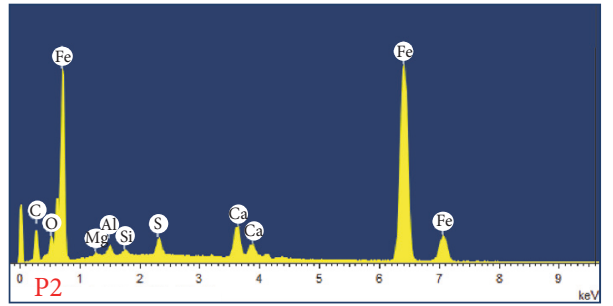

(c)

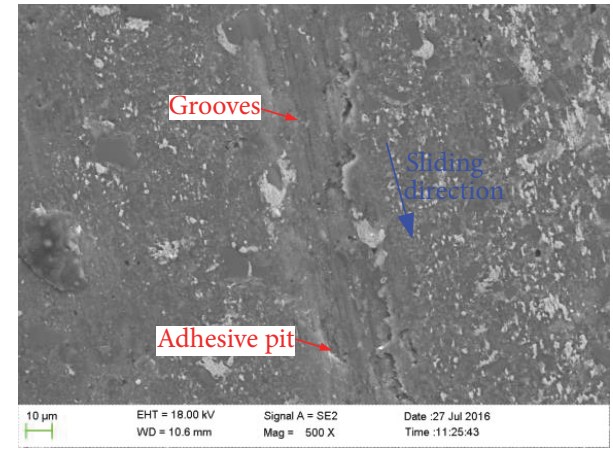

(b)

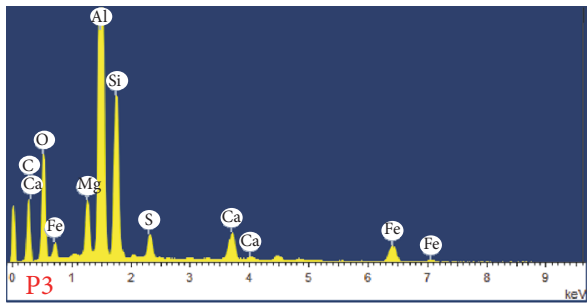

(d)

Figure 10: The surface topography and EDS of composites specimen for the test of $30^{\circ} \mathrm{C} \sim 300^{\circ} \mathrm{C}$ : (a) $200 \mathrm{x}$, (b) $500 \mathrm{x}$, (c) EDS of position P2, and (d) EDS of position P3.

severe grooves on the friction surface proved that the spherical particles have higher hardness than grinding materials. It can be seen from Figures 11(b) and 11(c) that the hard MMPs contain the debris coming from both SiCp/A356 composites and semimetallic materials. The morphology of MMPs proved that the compacted materials consist of broken $\mathrm{SiC}$ particles and mixed materials transferred from the semimetallic materials and aluminum matrix and experienced complex mechanical and chemical effects and oxidation.

Hard MMPs formed at high temperature and scratched the friction surface constantly. The MMPs began to scratch the surface of $\mathrm{SiCp} / \mathrm{A} 356$ composites after the TBFs had been destroyed, and then serious grooves formed on the $\mathrm{SiCp} / \mathrm{A} 356$ composites surface. In addition, the performance degradation of $\mathrm{SiCp} / \mathrm{A} 356$ composites and semimetallic materials at high temperatures exacerbate the formation of grooves $[11,12]$. It leads to decrease in the friction coefficient and increase in wear rate under high temperature.

In the dry sliding process, the constant TBFs were produced and covered on the surface of SiCp/A356 composites. The TBFs protected SiCp/A356 composites from direct contact with the coupling friction materials. With the existence of TBFs, the friction coefficient was stable and the wear rate 


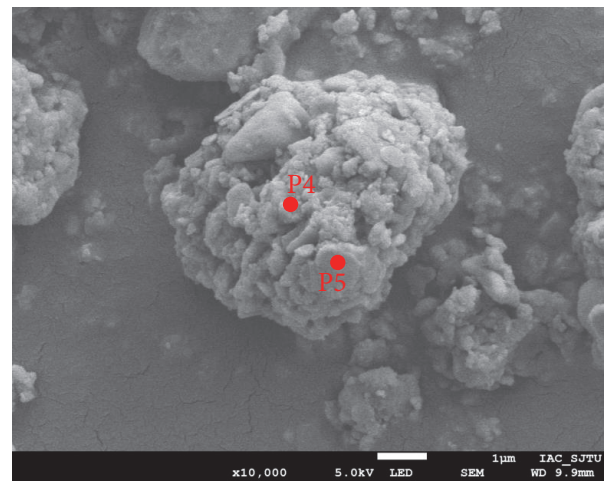

(a)

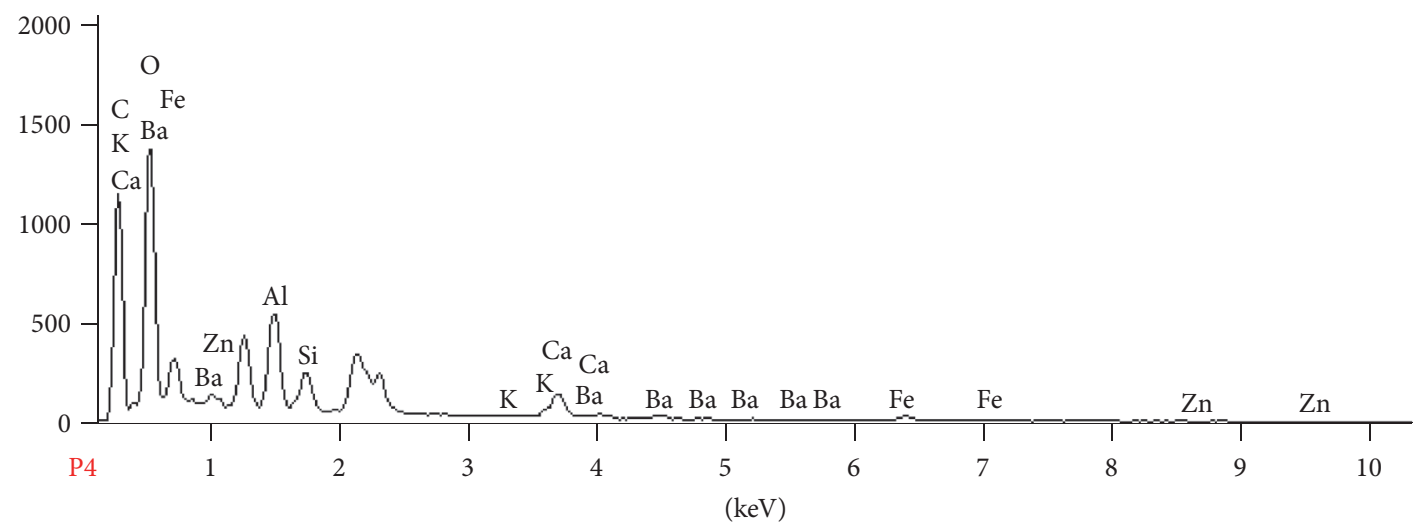

(b)

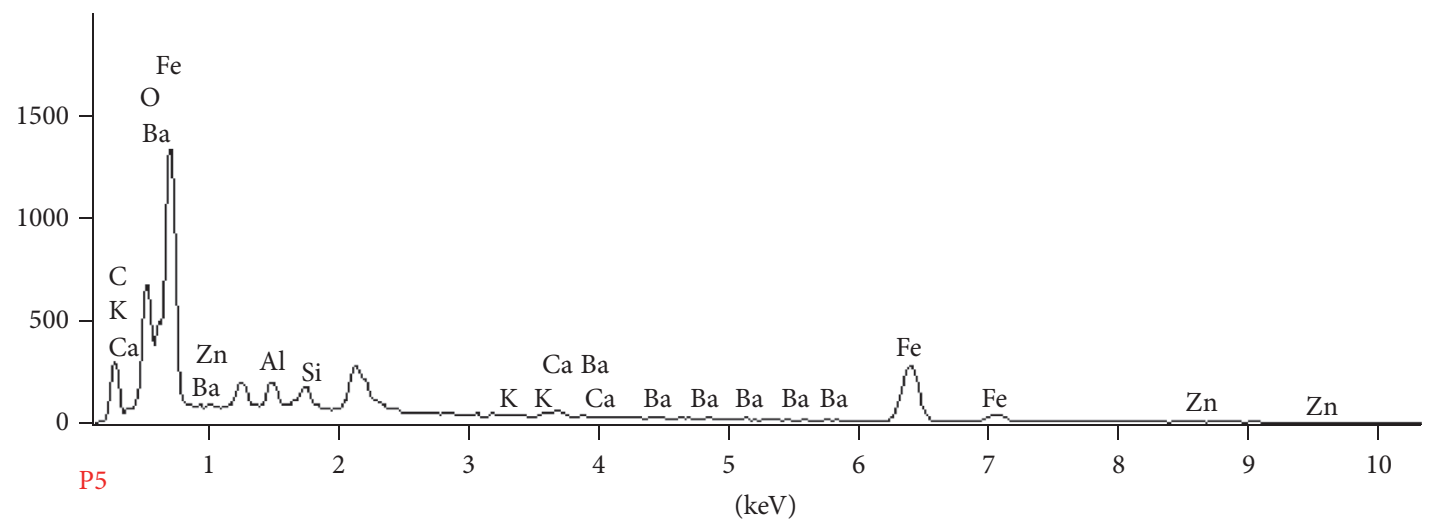

(c)

FIgURE 11: The wear debris and EDS of dry friction for the test of $30^{\circ} \mathrm{C} 300^{\circ} \mathrm{C}$ : (a) debris morphology, (b) EDS of position P4, and (c) EDS of position P5.

was lower. But the TBFs could be destroyed gradually with the rising temperature which is caused by cumulated friction heat. The surface of SiCp/A356 composites was exposed gradually and scratched by MMPs with higher hardness. The wear mechanism transferred from the third body films lubricated wear to the third body abrasive wear. It also turned out that the continuous TBFs have important effect on stabilizing the friction performance and extending wear life.

Figures 12 and 13 show the topography and element distribution at position P6 on the surface for the test at the temperature range of $100^{\circ} \mathrm{C} \sim 200^{\circ} \mathrm{C}$. Comparing with the test of $30^{\circ} \mathrm{C} \sim 200^{\circ} \mathrm{C}$ shown in Figure 8, the TBFs at the temperature range of $100^{\circ} \mathrm{C} \sim 200^{\circ} \mathrm{C}$ was discrete distributed, which have lower load capacity than continuous TBFs. The exposed surface worn against semimetallic materials directly and the hard MMPs scratched the surface of SiCp/A356 composites. Therefore, it led to serious grooves, delamination, and adhesion. The friction coefficient became fluctuated and wear rates of semimetallic materials were five times of $30^{\circ} \mathrm{C} \sim 100^{\circ} \mathrm{C}$.

The SiC particles were exposed and broken under the dry sliding test under the temperature level of $200^{\circ} \mathrm{C} \sim 300^{\circ} \mathrm{C}$. 


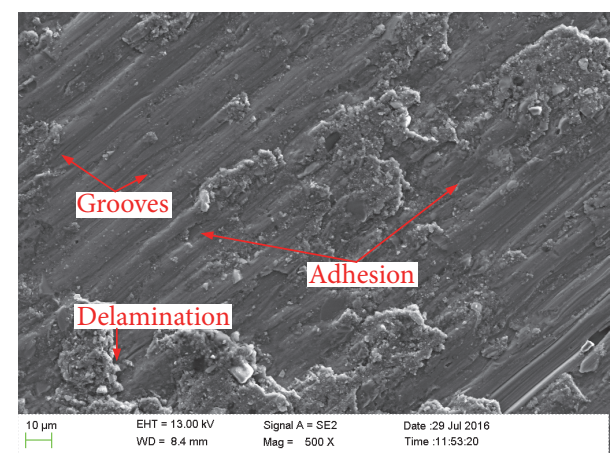

(a)

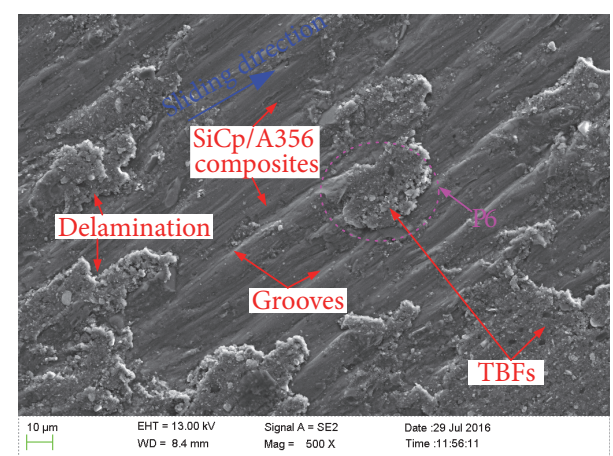

(b)

FIGURE 12: The surface topography of composites specimen for the test of $100^{\circ} \mathrm{C} 200^{\circ} \mathrm{C}$ : (a) $500 \mathrm{x}$ and (b) $500 \mathrm{x}$.

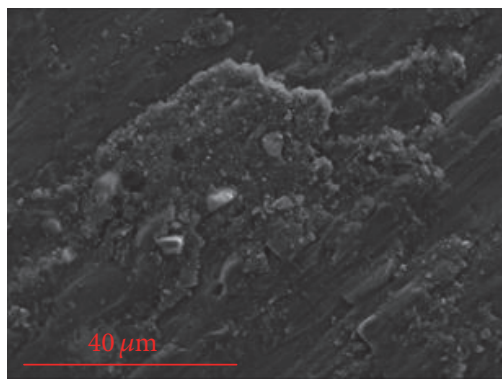

(a)

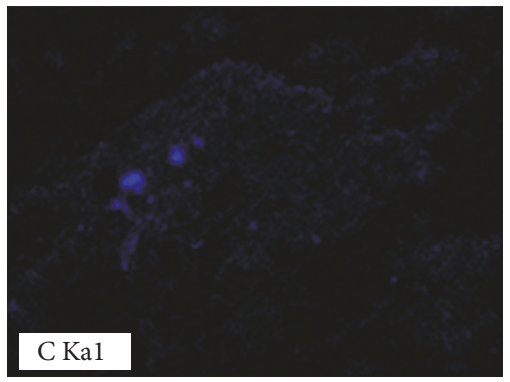

(d)

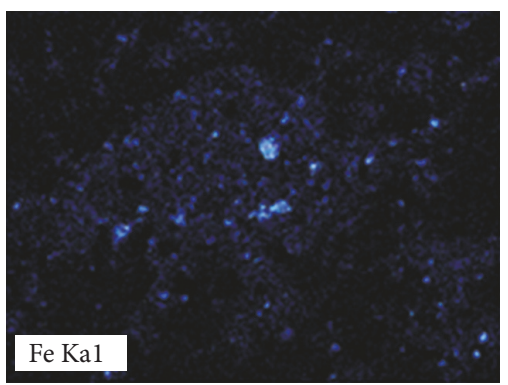

$(\mathrm{g})$

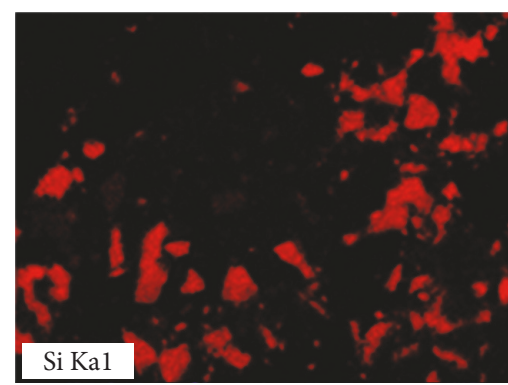

(b)

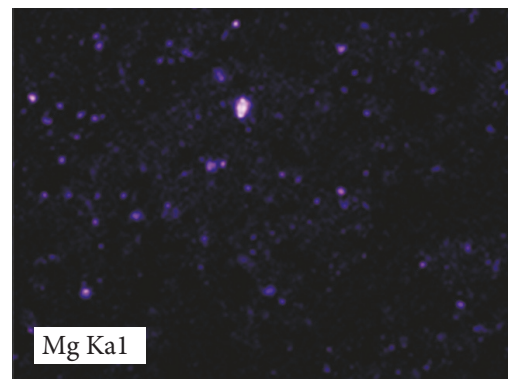

(e)

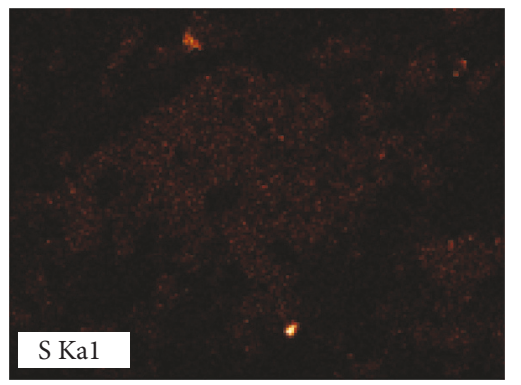

(h)

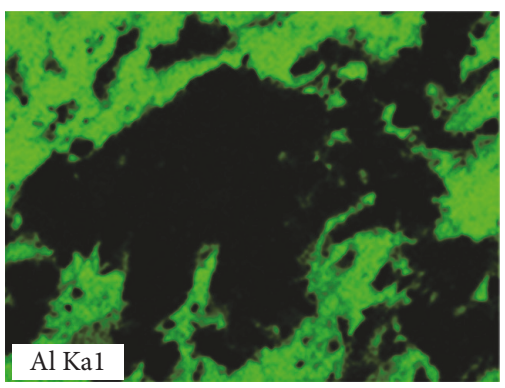

(c)

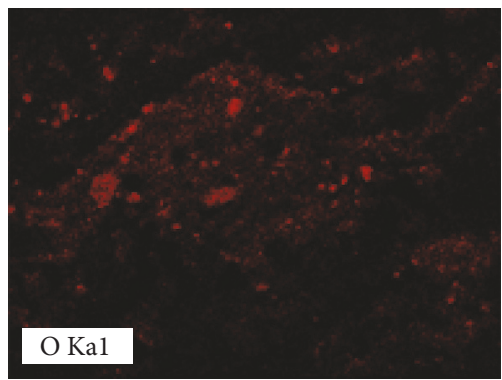

(f)

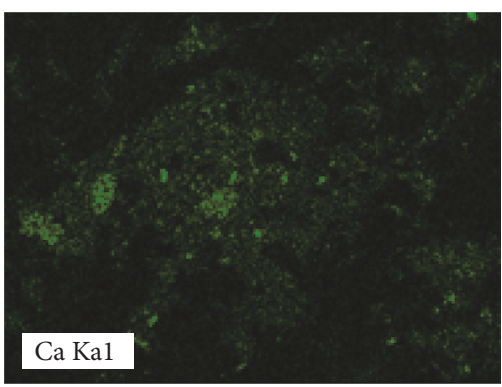

(i)

FIgURE 13: The surface element distribution of position P6 of composites specimen for the test of $100^{\circ} \mathrm{C} \sim 200^{\circ} \mathrm{C}$ : (a) surface topography, (b) $\mathrm{Si}$, (c) $\mathrm{Al}$, (d) C, (e) $\mathrm{Mg}$, (f) O, (g) Fe, (h) S, and (i) Ca. 


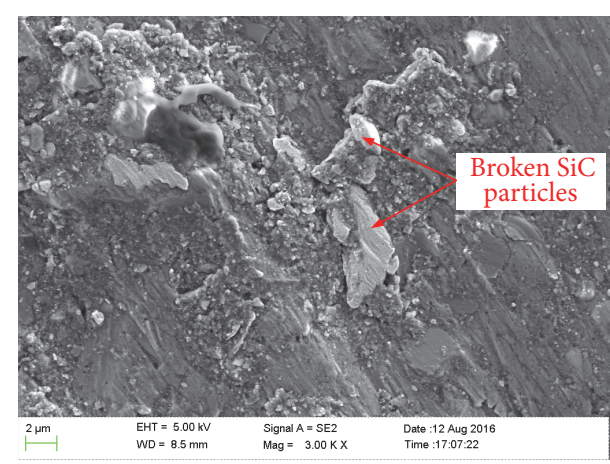

(a)

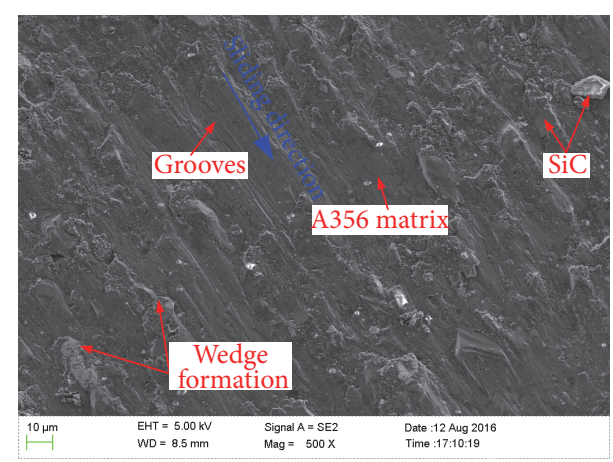

(b)

FIGURE 14: The surface topography of composites specimen for the test of $200^{\circ} \mathrm{C} 300^{\circ} \mathrm{C}$ : (a) $3000 \mathrm{x}$ and (b) $500 \mathrm{x}$.

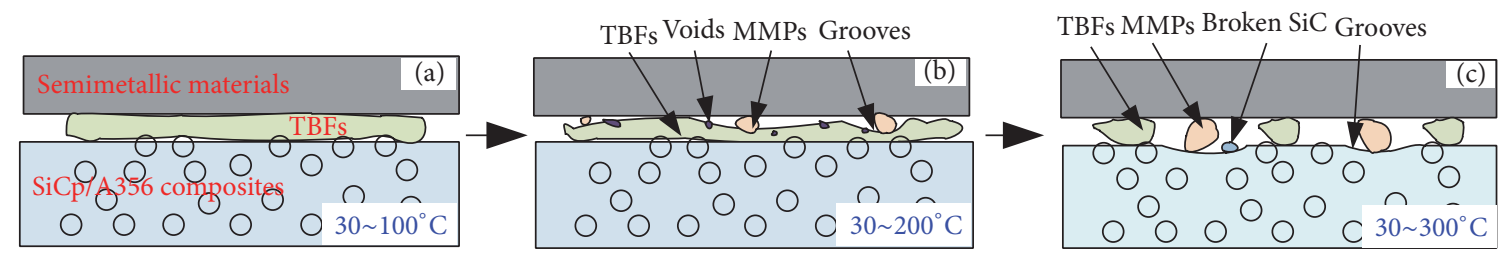

FIgURE 15: The transformation process of temperature effect on the surface third body films (TBFs) of dry friction: (a) $30^{\circ} \mathrm{C} \sim 100^{\circ} \mathrm{C}$, (b) $30^{\circ} \mathrm{C} \sim 200^{\circ} \mathrm{C}$, and (c) $30^{\circ} \mathrm{C} \sim 300^{\circ} \mathrm{C}$.

Thus, many severe wedge and grooves can be observed in Figure 14. The hard MMPs scratched the surface of $\mathrm{SiCp} / \mathrm{A} 356$ composites without the protection of TBFs. The reinforced $\mathrm{SiC}$ particles burst out of the surface to prevent the MMPs from cutting the surface of composites. The reinforced $\mathrm{SiC}$ particles were broken under the constant load pressure and high temperature. It resulted in the unstable friction coefficient. And wear rates of semimetallic materials were nearly seven times higher than that of $30^{\circ} \mathrm{C} \sim 100^{\circ} \mathrm{C}$.

The analysis above revealed that the $200^{\circ} \mathrm{C}$ was a transition temperature. The continuous TBFs were destroyed and discrete distributed above $200^{\circ} \mathrm{C}$. The hard MMPs scratched the $\mathrm{SiCp} / \mathrm{A} 356$ composites above the transition temperature and the protecting effect of TBFs for the SiCp/A356 composites was weakened.

Figure 15 exhibits the effect of elevated temperature produced by friction heat on the wear mechanism and transformation process of TBFs during dry friction. A layer of continuous TBFs emerged after dry friction, which is shown in Figures 15(a) and 7. The TBFs could protect the SiCp/A356 composites from being worn directly and play an important role in the third body lubricated wear. With the temperature rising, the material properties of the TBFs were reduced. With plenty of voids, adhesive pits and slight grooves appeared, as is shown in Figures 15(b) and 8. A lot of mechanically mixed particles (MMPs) appeared and rubbed on the surface. The MMPs experienced slight adhesive, delamination, and abrasive wear in the temperature range of $30^{\circ} \mathrm{C} \sim 200^{\circ} \mathrm{C}$. With the continuous rising in friction temperature, the surface films were gradually destroyed and the abrasive was intensified. The protective effect of the TBFs was further reduced and resulted in scratch on the surface of SiCp/A356 composites. Then severe adhesive wear and abrasive wear can be seen in Figures 15(c) and 10.

The TBFs have important protection effect on the $\mathrm{SiCp} / \mathrm{A} 356$ composites which can prevent or delay the severe abrasive wear. Although the friction heat could damage the TBFs, the surface morphology of SiCp/A356 composites has big difference whether there are TBFs before dry friction under high temperature or not, which can be displayed by comparing the surface morphology in Figures 8 and 12. The thickness and morphology of the surface films also affect the transition temperature.

\section{Conclusions}

The friction and wear behaviors of SiCp/A356 composites, which can be used for brake disc material for the train and automobile, were studied to analyze temperature effects on the wear mechanism, friction coefficient, and wear rates. It is necessary to have a better understanding in the influence of rising temperature on braking performance. The following conclusions can be drawn according to the discussion above.

(1) A beneficial layer of continuous third body films (TBFs) with thickness of 3-5 $\mu \mathrm{m}$ was generated on the surface of SiCp/A356 composite surface. TBFs can help to stabilize the friction coefficient below $200^{\circ} \mathrm{C}$. TBFs are also useful to reduce the wear loss by protecting the friction surface of composites and isolating the high temperature.

(2) The massive hard mechanically mixed particles (MMPs) were produced above $100^{\circ} \mathrm{C}$. MMPs consist of compacted materials containing broken $\mathrm{SiC}$ particles and 
mixed materials which are transferred from the semimetallic materials and aluminum matrix. The MMPs could lead to deep grooves and severe adhesive pit on the surface of composite above $200^{\circ} \mathrm{C}$. It is accompanied by decrease in friction coefficient and increase in wear rate.

(3) The transition temperature was found to be $200^{\circ} \mathrm{C}$. The third body films lubricated wear transfers to the third body abrasive wear above $200^{\circ} \mathrm{C}$. The supporting effect of particle changes to scratching the surface of composites because of broken and oxidation during the dry sliding process.

(4) The surface films could be gradually destroyed and discrete distributed and became thinner with the rising temperature. The wear mechanisms observed during friction test went through the third body lubricated wear in the test of $30^{\circ} \mathrm{C} \sim 100^{\circ} \mathrm{C}$ and mild adhesive wear and slight abrasive wear at $100^{\circ} \mathrm{C} \sim 200^{\circ} \mathrm{C}$. The wear mechanisms transferred to the severe adhesive and abrasive wear in the temperature range of $200^{\circ} \mathrm{C} \sim 300^{\circ} \mathrm{C}$.

\section{Conflicts of Interest}

The authors declare that there are no conflicts of interests regarding the publication of this paper.

\section{Acknowledgments}

The authors thank the financial support from the National Key Technology R\&D Program of China (2015BAG12B01-09), the National Nature Science Foundation of China (51271014 and 51371022), and the Fundamental Research Funds for the Beijing Jiaotong University (2015JBM076).

\section{References}

[1] D. J. Lloyd, "Particle reinforced aluminium and magnesium matrix composites," International Materials Reviews, vol. 39, no. 1, pp. 1-23, 1994.

[2] H. Nakanishi, K. Kakihara, A. Nakayama, and T. Murayama, "Development of aluminum metal matrix composites (AlMMC) brake rotor and pad," JSAE Review, vol. 23, no. 3, pp. 365-370, 2002.

[3] P. Rohatgi, "Cast aluminum-matrix composites for automotive applications," JOM, vol. 43, no. 4, pp. 10-15, 1991.

[4] T. Zeuner, P. Stojanov, P. R. Sahm, H. Ruppert, and A. Engels, "Developing trends in disc brake technology for rail application," Materials Science and Technology, vol. 14, no. 9-10, pp. 857-863, 1998.

[5] N. Natarajan, S. Vijayarangan, and I. Rajendran, "Wear behaviour of A356/25SiCp aluminium matrix composites sliding against automobile friction material," Wear, vol. 261, no. 7-8, pp. 812-822, 2006.

[6] R. K. Uyyuru, M. K. Surappa, and S. Brusethaug, "Tribological behavior of Al-Si-SiCp composites/automobile brake pad system under dry sliding conditions," Tribology International, vol. 40, no. 2, pp. 365-373, 2007.

[7] S. Zhang and F. Wang, "Comparison of friction and wear performances of brake material dry sliding against two aluminum matrix composites reinforced with different $\mathrm{SiC}$ particles," Journal of Materials Processing Technology, vol. 182, no. 1-3, pp. 122-127, 2007.
[8] A. Daoud and M. T. Abou El-khair, "Wear and friction behavior of sand cast brake rotor made of A359-20 vol\% SiC particle composites sliding against automobile friction material," Tribology International, vol. 43, no. 3, pp. 544-553, 2010.

[9] D. Zhao, F. R. Tuler, and D. J. Lloyd, "Fracture at elevated temperatures in a particle reinforced composite," Acta Metallurgica Et Materialia, vol. 42, no. 7, pp. 2525-2533, 1994.

[10] H. Zhang, Y. He, and L. Li, "Tensile deformation and fracture behavior of spray-deposition $7075 / 15 \mathrm{SiCp}$ aluminum matrix composite sheet at elevated temperatures," Materials Characterization, vol. 59, no. 8, pp. 1078-1082, 2008.

[11] D.-G. C. Syu and A. K. Ghosh, "The effect of temperature on the fracture mechanism in 2014A1/15vol.\%Al2O3 composite," Materials Science and Engineering A, vol. 184, no. 1, pp. 27-35, 1994.

[12] T. Liu and S. K. Rhee, "High temperature wear of semimetallic disc brake pads," Wear, vol. 46, no. 1, pp. 213-218, 1978.

[13] S. Zhang and F. Wang, "Comparison of friction and wear performances of brake materials containing different amounts of $\mathrm{ZrSiO} 4$ dry sliding against $\mathrm{SiCp}$ reinforced $\mathrm{Al}$ matrix composites," Materials Science and Engineering A, vol. 443, no. 1-2, pp. 242-247, 2007.

[14] M. A. Martinez, A. Martin, and J. Llorca, "Wear of Al$\mathrm{Si}$ alloys and $\mathrm{Al}-\mathrm{Si} / \mathrm{SiC}$ composites at ambient and elevated temperatures," Scripta Metallurgica et Materiala, vol. 28, no. 2, pp. 207-212, 1993.

[15] S. Wilson and A. T. Alpas, "Effect of temperature on the sliding wear performance of $\mathrm{Al}$ alloys and $\mathrm{Al}$ matrix composites," Wear, vol. 196, no. 1-2, pp. 270-278, 1996.

[16] A. Martín, M. A. Martínez, and J. Llorca, "Wear of SiCreinforced Al-matrix composites in the temperature range 20200 ○C, Wear, vol. 193, no. 2, pp. 169-179, 1996.

[17] J. Singh and A. T. Alpas, "Elevated temperature wear of Al6061 and Al6061-20\%Al2O3," Scripta Metallurgica et Materiala, vol. 32, no. 7, pp. 1099-1105, 1995.

[18] J. E. Allison and G. S. Cole, "Metal-matrix composites in the automotive industry: Opportunities and challenges," JOM, vol. 45, no. 1, pp. 19-24, 1993.

[19] M. Muratoǧlu and M. Aksoy, "Abrasive wear of 2124Al-SiC composites in the temperature range 20-200 ०C," Journal of Materials Processing Technology, vol. 174, no. 1-3, pp. 272-276, 2006.

[20] L. Yao-hui, D. Jun, Y. Si-rong, and W. Wei, "High temperature friction and wear behaviour of $\mathrm{Al} 2 \mathrm{O} 3$ and/or carbon short fibre reinforced Al-12Si alloy composites," Wear, vol. 256, no. 3-4, pp. 275-285, 2004.

[21] J. Singh and A. T. Alpas, "High-temperature wear and deformation processes in metal matrix composites," Metallurgical and Materials Transactions A: Physical Metallurgy and Materials Science, vol. 27, no. 10, pp. 3135-3148, 1996.

[22] J. Rodríguez, P. Poza, M. A. Garrido, and A. Rico, "Dry sliding wear behaviour of aluminium-lithium alloys reinforced with SiC particles," Wear, vol. 262, no. 3-4, pp. 292-300, 2007.

[23] S. M. R. Mousavi Abarghouie and S. M. Seyed Reihani, "Investigation of friction and wear behaviors of $2024 \mathrm{Al}$ and 2024 $\mathrm{Al} / \mathrm{SiCp}$ composite at elevated temperatures," Journal of Alloys and Compounds, vol. 501, no. 2, pp. 326-332, 2010.

[24] F. Labib, H. M. Ghasemi, and R. Mahmudi, "Dry tribological behavior of $\mathrm{Mg} / \mathrm{SiC}_{\mathrm{p}}$ composites at room and elevated temperatures," Wear, vol. 348-349, pp. 69-79, 2016. 
[25] X. Y. Li and K. N. Tandon, "Microstructural characterization of mechanically mixed layer and wear debris in sliding wear of an $\mathrm{Al}$ alloy and an Al based composite," Wear, vol. 245, no. 1-2, pp. 148-161, 2000.

[26] B. Venkataraman and G. Sundararajan, "Correlation between the characteristics of the mechanically mixed layer and wear behaviour of aluminium, Al-7075 alloy and Al-MMCs," Wear, vol. 245, no. 1-2, pp. 22-38, 2000.

[27] D. Majcherczak, P. Dufrénoy, and M. Naï-Abdelaziz, "Third body influence on thermal friction contact problems: Application to braking," Journal of Tribology, vol. 127, no. 1, pp. 89-95, 2005.

[28] B. Venkataraman and G. Sundararajan, "The sliding wear behaviour of Al-SiC particulate composites - II. The characterization of subsurface deformation and correlation with wear behaviour," Acta Materialia, vol. 44, no. 2, pp. 461-473, 1996. 

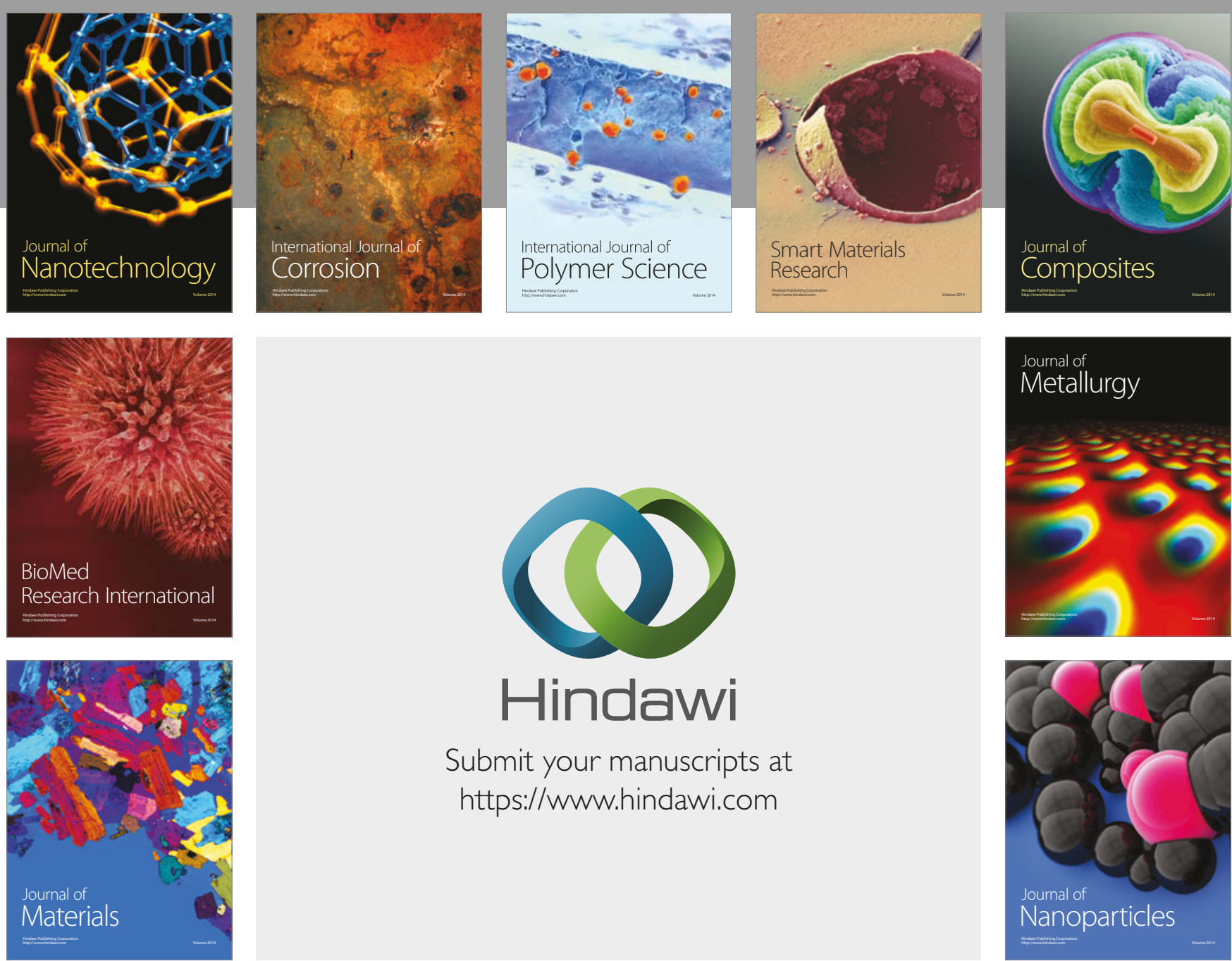

\section{Hindawi}

Submit your manuscripts at

https://www.hindawi.com
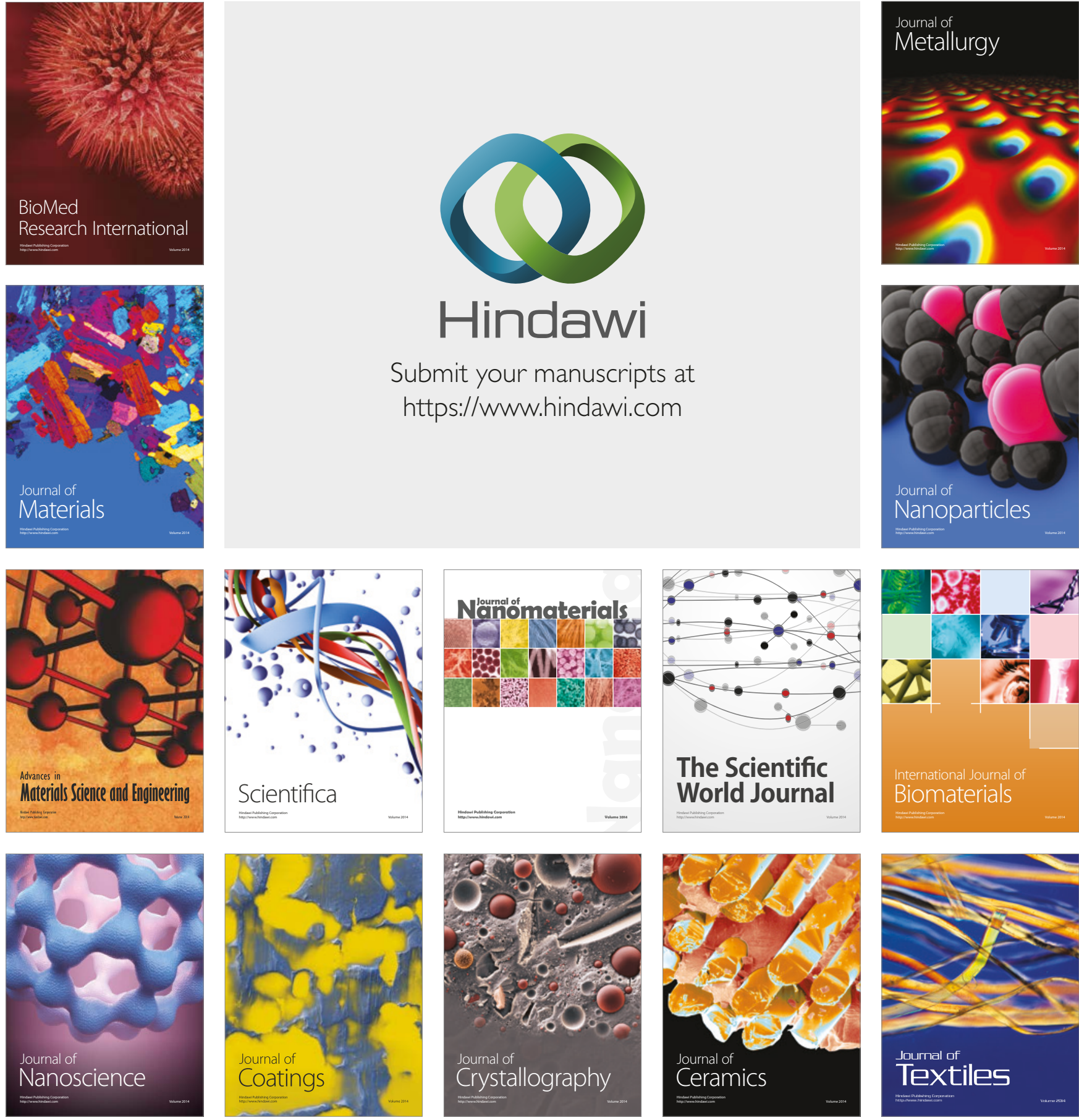

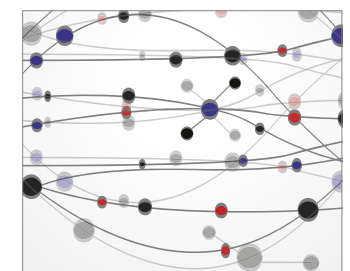

The Scientific World Journal
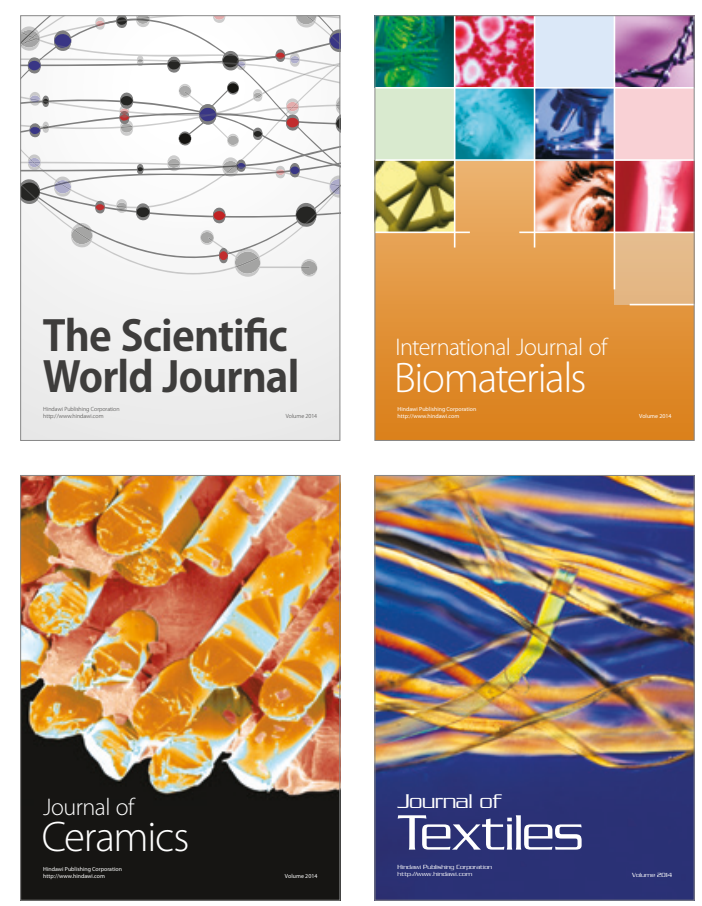